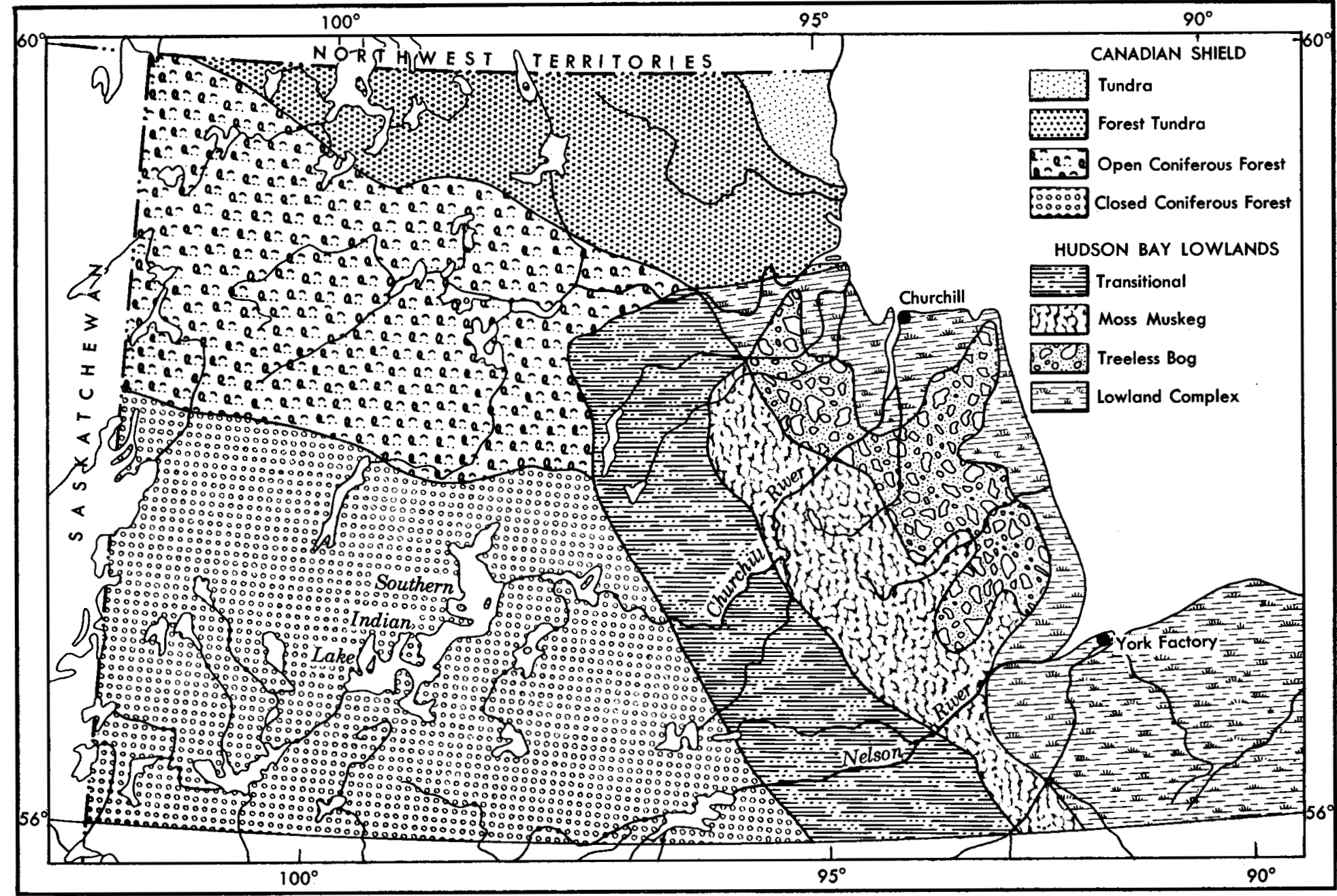

Fig. 1. Map showing the vegetation zones of Manitoba north of the 56th parallel. The area east of the 92nd meridian has not been examined and the suggestion that it is occupied solely by the Lowland Complex Type is tentative. 


\title{
THE VEGETATION OF NORTHERN MANITOBA V. ESTABLISHING THE MAJOR ZONATION
}

\author{
J. C. Ritchie*
}

\section{Introduction}

$\mathbf{O}^{n}$ $\mathrm{NE}$ of the first requirements of a study of the vegetation of a large, poorly known region is the compilation of maps showing the extent of the various categories of plant cover. Investigation must begin with extensive work to establish the general configuration of vegetation zones and community types and be followed by detailed intensive study of the composition, structure, dynamics, and ultimately the ecology of the vegetation. In the present investigation extensive and intensive studies have proceeded more or less simultaneously, but the representativeness of the latter can be assessed only after the general work has been done.

The work of Hare and his associates in eastern Canada (Hare 1955, 1959) has given impetus and direction to attempts to map accurately the major zones of vegetation in boreal and arctic North America, but at present there is no reliable map showing the zonation of vegetation in any large region of Canada west of Hudson Bay. As Hare points out our knowledge of vegetation zones in northern Canada has until recently depended solely on the reports of travellers whose observations were often confined to watercourses. However, in the last two decades a rich source of information has become available in the vertical air photographs of much of Canada.

An effort is being made to use this source of information to establish the main boundaries between the zones of vegetation in northern Manitoba. This information is making it possible to compile maps of two types - those showing small areas in detail, at scales of about 1:30,000 (for example, Ritchie 1958), and others of large regions showing the major zones of vegetation. The present report is based on a simple map of the latter type (Fig. 1). Work is in process on a vegetation map of the area dealt with here, using the Topographical Map Sheets (scale 1.500,000) as base maps. It uses methods by which Hare and Taylor (1956) have mapped the vegetation of LabradorQuebec at the 1:500,000 scale. For the present an area of approximately 300,000 square kilometers ( 100,000 square miles) is being studied, comprising that part of Manitoba bounded in the north by the District of Keewatin, in the west by Saskatchewan, in the south by the 56th parallel, and in the east by the 92nd meridian (Fig. 2).

\footnotetext{
*Department of Botany, University of Manitoba, Winnipeg, Manitoba, Canada.
} 
Before presenting the results, brief reference should be made to work of a similar nature by other investigators in Manitoba, since some of it has been of value in developing the present approach. The fully illustrated, detailed report of Cheney and Brown Beckel (1955) on the Churchill area is of value, and will long be referred to for accurate information on the landforms and vegetation of this particular area. Unfortunately it was never published. Beckel (1958) has applied the methods of air photographic interpretation in a selected area of northwestern Manitoba, in connection with studies of the range of the Barren Ground caribou. Following field work in

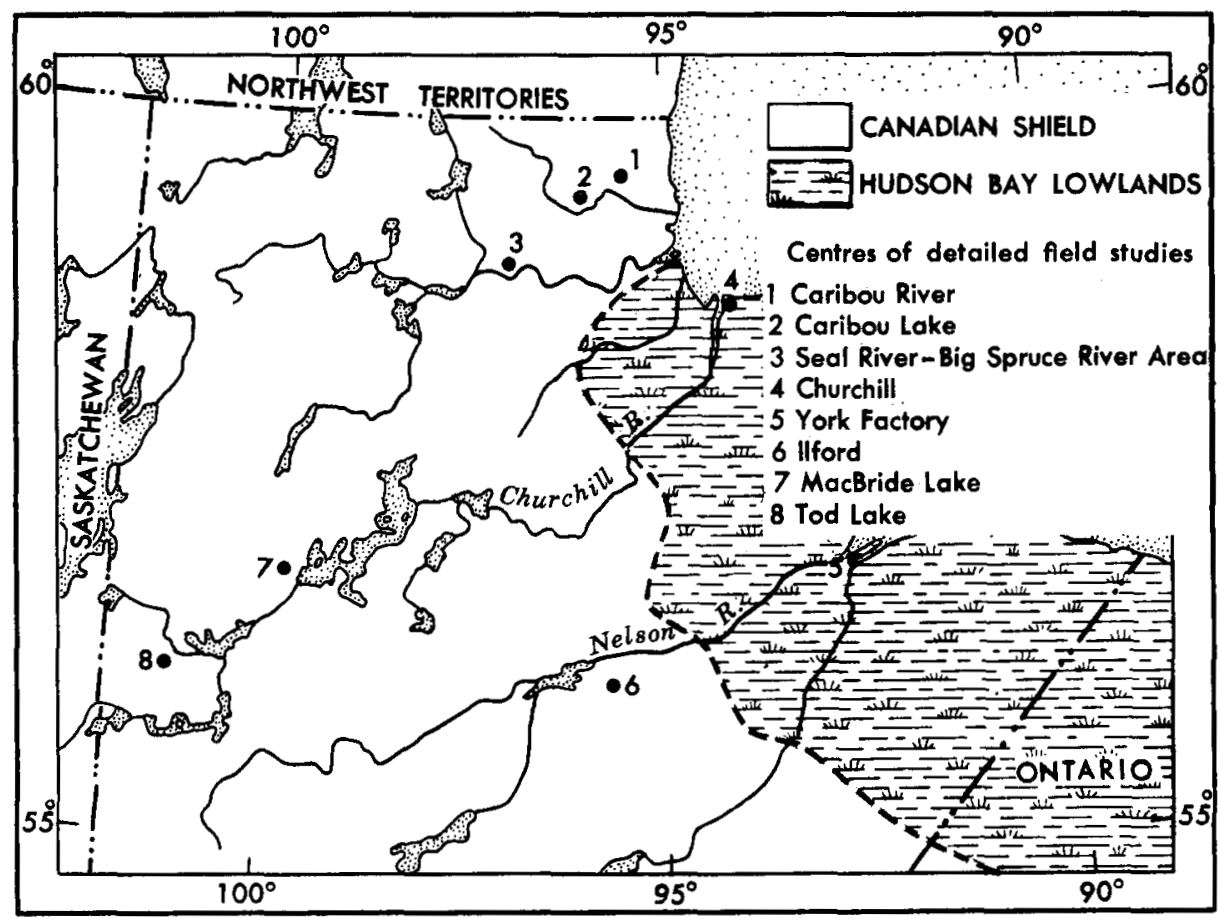

Fig. 2. Map of northern Manitoba showing the main physiographic regions and the centres of detailed field study.

the Churchill area, Radforth (1952) has proposed a completely independent "classification of muskeg" which appears to be designed solely for use in practical applications. It is doubtful if this system will be of use in basic studies of vegetation. As Hustich (1957) and Sjörs (1958) point out, the vegetation and processes of peatlands in the Hudson Bay Lowlands of Canada and those of Europe are remarkably similar, the differences between them being largely of a minor floristic nature. Accordingly, any basic classification of peatlands should take as its starting point the extensive European literatures. Likewise, Radford's "Organic terrain organization from the air" (1958) is of very limited use to the geobotanist. 


\section{Methods}

Field studies have been carried out in northern Manitoba at the following places and times: MacBride Lake area $\left(56^{\circ} 52^{\prime} \mathrm{N}\right.$. $99^{\circ} 57^{\prime} \mathrm{W}$.) and Tod Lake area $\left(56^{\circ} 45^{\prime} \mathrm{N} .101^{\circ} 48^{\prime} \mathrm{W}\right.$.) in 1955 , Great Island area of Seal River $\left(59^{\circ} \mathrm{N}\right.$. $96^{\circ} 45^{\prime} \mathrm{W}$.) in 1956 , Caribou Lake and Caribou River $\left(59^{\circ} 20^{\prime} \mathrm{N}\right.$. $95^{\circ} 10^{\prime} \mathrm{W}$.) in 1957 , Ilford $\left(56^{\circ} 04^{\prime} \mathrm{N} .95^{\circ} 36^{\prime} \mathrm{W}\right.$.) and Lower Hayes River $\left(57^{\circ} \mathrm{N} .92^{\circ} 20^{\prime} \mathrm{W}\right.$.) in 1959 . The Churchill area $\left(58^{\circ} 40^{\prime} \mathrm{N} .94^{\circ} \mathrm{W}\right.$.) was examined in detail in 1954 , and for shorter periods in 1956, 1957, and 1958. (Reports on the flora and vegetation of some of these areas are listed in the References). The stations were selected partly because they were thought to be representative and partly for convenience of access and transportation. In addition, sundry flights over the region increased the author's familiarity with the general features of the vegetation.

At each station, a set of vertical air photographs (at scales between 1:20,000 and 1:60,000) was used in the field (and later in the laboratory) and some ability has gradually been acquired in the interpretation of these photographs in terms of vegetation and landforms. Detailed vegetation maps have been compiled for the MacBride Lake, Seal River, Caribou Lake, and Lower Hayes River areas (only the first has been published so far) and in each attempts were made to extend the interpretation and mapping into adjacent unexplored areas. By the end of 1958 a set of "keys" had been prepared, similar to that published (Ritchie 1958), in which summaries are given of the photographic characteristics and physiographic affinities of the vegetation.

It was thought that it might be possible to extend the survey of photographs to the large areas in northern Manitoba where no field work had been done. Accordingly, the National Air Photo Library of the Department of Mines and Technical Surveys, Ottawa was visited in order to examine photographs of areas for which the writer had no coverage. Flight lines were selected that passed from areas examined in the field into unexplored areas, until the entire area had been covered. A flight line of say 100 photographs was studied by examining every photograph rapidly and then studying pairs critically with a magnifying stereoscope at intervals of roughly 10 photographs, especially where a change in vegetation type was suspected. Approximately 3,000 photographs were examined, about 10 per cent of them stereoscopically, and a further 2,000 have been examined in detail in the laboratory. The method depends much on personal experience and familiarity with air photographs. The accuracy of the zonal map (Fig. 1), which cannot be known fully until it has been tested widely in the field and the 1:500,000 maps have been compiled, will be a direct measure of the soundness of the photographic interpretation.

For each photograph or set of continuous photographs, where there was no change in vegetation type, the following information was recorded in abbreviated form: (a) the types of landforms present, indicating the proportions of each; (b) the drainage patterns; (c) the types of vegetation occupying various physiographic positions such as outcrop ridges, eskers, till ridges, 
sand plains, drumlins, alluvium, and poorly drained depressions; (d) any evidence of recent disturbance, as by fire. For each set of photographs an estimate (visual) was made of the percentage of upland sites occupied by the various types of vegetation; in the Hudson Bay Lowlands area, where upland sites are rare, all recognizable types of vegetation were given an estimated percentage value. The data were then assembled and the zones of change in vegetation type entered on the base maps. In Fig. 1 these zones are shown as single lines, but nowhere was a boundary between zones so abrupt. Transition zones between the types varied from $20 \mathrm{~km}$. to $100 \mathrm{~km}$. in width, but it is hoped that these can be better defined on the 1:500,000 maps.

A weakness of this method is that the boundaries have been determined by criteria that are neither wholly objective nor precise. The boundaries on the Canadian Shield physiographic region were ascertained as follows:
boundary
Closed Coniferous Forest ( $<20$ per cent of mesic sites with open-crown forest) Open Coniferous Forest ( $>20$ per cent of mesic sites with open-crown forest)
boundary $\begin{aligned} & \text { Open Coniferous Forest }(<20 \text { per cent of mesic sites with scrub forest) } \\ & \text { Forest Tundra ( }>20 \text { per cent of mesic sites with scrub forest) }\end{aligned}$
boundary $\frac{\text { Forest Tundra ( }<75 \text { per cent of upland sites with heath tundra) }}{\text { Tundra }(>75 \text { per cent of upland sites with heath tundra) }}$

In practice the method produces boundaries that indicate actual changes in vegetation physiognomy, but it does not take into account the important fact that the effects of fires have been so widespread in this region that few areas are occupied by stable, mature vegetation. For example, the southern boundary of the Forest-Tundra zone as shown is almost certainly considerably farther south than the southern boundary of the "potential" forest tundra. Therefore, the zone boundaries have been adjusted according to the author's knowledge of the area, which procedure has made them rather subjective. This is undesirable but perhaps unavoidable at present. Probably both actual and potential vegetation should be mapped, if enough were known about the relationships of the two.

\section{The zones of vegetation}

The area is occupied by two physiographic regions, the continental part of the Hudson Bay Lowlands and the Canadian Shield (Fig. 2). The zones of vegetation found in each are treated separately, since it is likely that the distinctive nature of the vegetation of the Hudson Bay Lowlands is controlled primarily by the physiography of the region. This primary division of vegetation zones accords with the views of Hustich (1957) but it may prove to be invalid after further work. In this context the term vegetation zones describes a geographical region occupied by a number of plant communities and characterized either by the prevalence of one or by a particular proportion of two or more communities.

Within the physiographic regions there are zones of vegetation whose limits have been ascertained by the methods described above. In the shield 


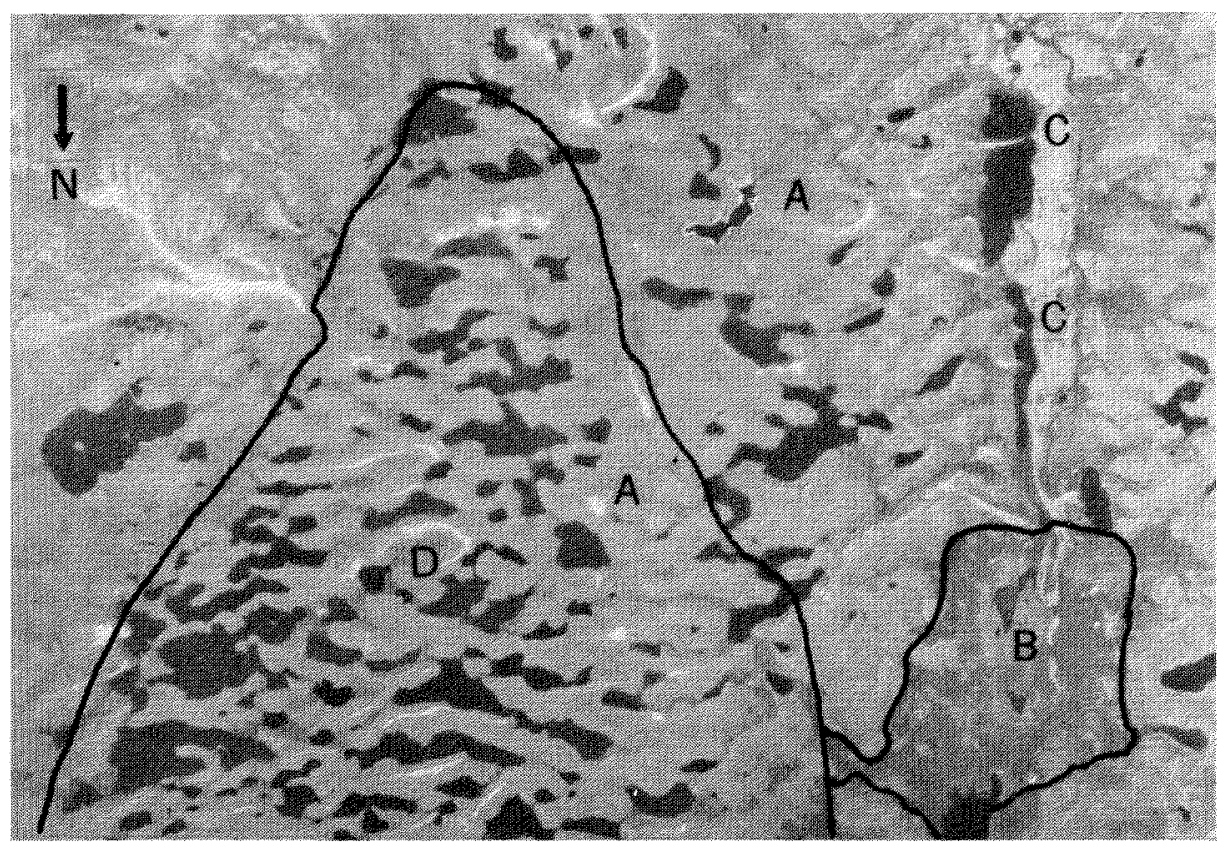

Fig. 3. Vertical air photograph A 14678-130 (scale 1:60,000) showing an area of Tundra northeast of Caribou Lake. The vegetation on the uplands is a heath tundra (A) with scrub spruce in depressions and along watercourses (B). Conspicuous landforms are the esker (C) and the area of washboard moraine (D, outlined). (This illustration and those following are parts of R.C.A.F. photographs; their publication here has been authorized).

region the zones are divided primarily on the basis of physiognomic criteria into Tundra, Forest-Tundra, Open Coniferous Forest, and Closed Coniferous Forest. In the lowlands, the zones are defined by the physiognomy of the vegetation and the surface pattern of the land.

In the following paragraphs the vegetation, physiography, and photographic appearance of each zone will be described. Under photographic appearance are included the tone, texture, and structure that can be detected by stereoscopic examination of vertical air photographs. The designations of tone have been determined with the Munsell Color Chart. The absolute achromatic tones are used with the Munsell notations, as follows: white (N8 - N9); light grey (N7); grey (N5 - N6); dark grey (N4); very dark grey (N3); and black (N1 - N2). They are provided as additional guiding information, but it is clear that the varying quality of the negatives and prints precludes any general application of tone criteria in interpretation.

\section{Canadian Shield region}

(a) Tundra (Fig. 3)

The summits and upper slopes of ridges are occupied by a community dominated by ericoid shrubs and fruticose lichens. The chief species (no 
detailed descriptions of the vegetation are given in this paper. They can be found in the references listed, others will be published later) are Vaccinium uliginosum, V. vitis-idaea ssp. minor, Empetrum hermaphroditum, Loiseleuria procumbens, Arctostaphylos alpina, with Cladonia rangiferina, $C$. rangiformis, C. mitis, Cetraria nivalis, and C. islandica. Locally Diapensia lapponica, Phyllodoce caerulea, and Rhododendron lapponicum form distinct associations. Lower slopes and river banks bear phanerophytic vegetation, dominated by Salix species (chiefly S. planifolia), Betula glandulosa, and Alnus crispa. Poorly drained areas are occupied by thin wet peat, bearing communities dominated by Eriophorum spissum, Scirpus caespitosus ssp. austriacus, Carex rotundata, C. paupercula, and C. stans. Elsewhere, deeper and drier peats have Sphagnum ssp. with Andromeda polifolia, Rubus chamaemorus, Vaccinium uliginosum, and Ledum decumbens. Along rivers, on alluvial soils and esker slopes groups of Picea glauca are common, suggesting that the almost complete absence of trees is not controlled directly by the climate.

The area has considerable relief inland, with extensive morainic ridges (local areas of washboard or minor moraine are found), eskers, raised beaches, and occasional ridges of outcropping bedrock. On the photographs, tundra heaths are light grey to grey (N6 - N7) in tone, shrub communities are grey (N5), cottongrass-sedge bogs are light grey to white (N8), and the bare sand of eskers and beaches is white (N9). The heaths and shrub areas lack structure and texture. Bog vegetation is flat, but often shows large polygons.

\section{(b) Forest-Tundra (Fig. 4)}

Field studies in this region (Ritchie, 1959) have shown that to a certain extent man has influenced the nature of the vegetation. Forest fires and felling have removed many trees from upland sites and treeless heath prevails. However, there is evidence in certain areas that the tundra heath of dry ridges and summits is a stable type, so for the present the name "ForestTundra" is used. From the tundra zone in the northeast corner of the province to the areas of continuous forest at the southern limit of the Subarctic there is a gradual transition of vegetation and the boundaries shown in Fig. 2 are arbitrary.

The tundra of upland slopes is floristically and physiognomically similar to that of the Tundra zone. The chief species are Vaccinium uliginosum, $V$. vitis-idaea ssp. minor, Loiseleuria procumbens, Empetrum hermaphroditum, Cladonia mitis, C. rangiferina, and Cetraria nivalis.

On lower slopes there is a scrubby vegetation of depauperate Picea mariana with Betula glandulosa. In basins where drainage is slightly impeded shallow peats develop, bearing stands of small trees of black spruce, with the ground vegetation dominated by Ledum groenlandicum, Sphagnum ssp., Vaccinium vitis-idea ssp. minor, and Rubus chamaemorus. In areas of poorer drainage, tracts of treeless vegetation prevail, with mainly Eriophorum spissum, Carex stans, C. capitata, C. rariflora, and Scirpus caespitosus. 
Alluvial substrata and eskers bear stands of white spruce, closed on moist sites and open on the drier sites, usually on eskers. The trees in the alluvial deposits often show excellent growth, a height of $20 \mathrm{~m}$. and $36 \mathrm{~cm}$. d.b.h. at 120 years being typical. There is a characteristic sequence of vegetation from younger to older alluvial deposits, and it seems likely that this change is seral (successional) as well as spatial. The zones vary from a sedgegrass pioneer community through zones of shrub (Betula glandulosa and Salix ssp.), invading trees of Larix laricina and Picea glauca, to a pure stand of white spruce with a herb-moss ground layer and a few tall shrubs. Older sites, where deep peat has accumulated, show evidence of a replacement of white spruce by black spruce.

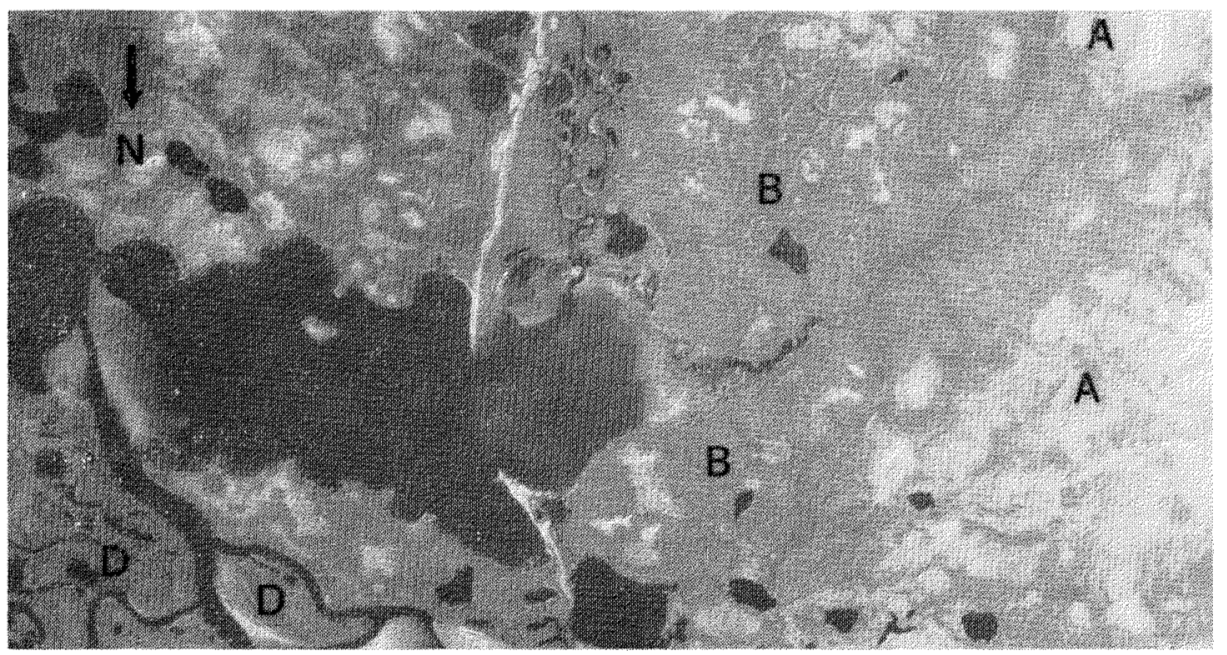

Fig. 4. Vertical air photograph A 14678-126 (scale 1:60,000) showing an area of Forest Tundra at Caribou Lake. Visible are tundra (A), scrub spruce forest (B), and alluvial deposits bearing a complex of pioneer and stable closed forest types (D).

In the Forest-Tundra zone and in the Open Coniferous Forest zone are numerous thick deposits of stratified peat that occur often as residual mantles on islands and lake shores and show conspicuous vertical faces 2 to $5 \mathrm{~m}$. high, where the peat is being eroded slowly. Detailed descriptions of them are found in other reports, (Ritchie 1959). Their surface is covered with tundra vegetation, a heath tundra on dry deposits and a sedge-cotton grass tundra on wetter sites. Often they show large polygonal fissures.

Physiographically this area differs from the Tundra zone only in the greater number of large eskers, and the smaller amounts, especially inland, of marine sediments and beach material.

On the photographs the following range of tones is found: tundra heaths - light grey (N7); scrubby black spruce forest - dark grey to very dark grey (N5 - N4); birch and willow scrub - grey (N6); sedge-cotton grass 
tundra - light grey (N5); esker and beach sands - white (N8). Upland heath and birch-willow scrub are textureless and structureless, and can be distinguished only by colour and by assuming that their physiographic positions are consistent. Black spruce muskeg shows only slight stippling under the stereoscope. White spruce stands on alluvium show the same tone as black spruce on peat, but are readily distinguished by the medium stippling and the conspicuous tall spires of the trees that often form a regular palisade along the banks of channels and oxbows. Deep peats with tundra are characterised by polygon patterns and the prevalence of small lakes and ponds.

\section{(c) Open Coniferous Forest (Fig. 5)}

The main feature of this zone is the prevalence on upland sites of stands of well-spaced conifers, with a ground vegetation consisting of two components - a mat of lichens, closely associated with low prostrate shrubs (Vaccinium vitis-idaea ssp. minor and Empetrum hermaphroditum) and a discontinuous stratum of medium shrubs (chiefly Betula glandulosa, Salix myrtillifolia, and S. arctica). Picea mariana (black spruce) is the commoner of the spruces, forming the tree layer on drift ridges and hills. On eskers and floodplains $P$. glauca (white spruce) replaces black spruce. Trees of black spruce about 200 years old seldom exceed $9 \mathrm{~m}$. in height and $15 \mathrm{~m}$. d.b.h. Many show extensive reproduction by layering. On esker slopes along streams white spruce trees $18 \mathrm{~m}$. high and $70 \mathrm{~cm}$. d.b.h. at 200 years of age have been observed in this zone.

Poorly drained sites are occupied by muskeg and bog vegetation, and in many areas deep residual peats are common (described in detail in Ritchie 1959, pp.28-31) In this zone and in the Tundra and Forest-Tundra, fens are rare.

In Northern Manitoba the nature and extent of open coniferous forests appear to differ markedly from those described by other workers from regions east of Hudson Bay. There the open coniferous region (the lichen woodland of Hare and Taylor 1956) appears to have extensive areas of Picea-Cladonia forest, with the Cladonia layer deep and well developed. In many areas of Northern Manitoba mesic sites within this zone are occupied by secondary communities as a result of extensive fires. It has been found, in an admittedly small sample of areas, that the deep Cladonia carpet is often absent and replaced by a sparser lichen mat with prostrate shrubs, where the lichen Stereocaulon appears in greater abundance than species of Cladonia. Following the experience of Scandinavian workers it has been suggested (Ritchie 1959, p.37) that this shift in lichen dominance may sometimes be due to overgrazing by Barren Ground caribou. The importance of the vegetation of the Forest Tundra and Open Coniferous Forest zones in studies of the ecology of the Barren Ground caribou is clear from the work of Banfield (1954), and Darling and Leopold (1954). At this stage it can be said with certainty only that in these zones the proportion of mesic sites occupied by stable or mature 
vegetation is remarkably small - as little as 5 per cent in areas that the writer has examined, although this figure is probably lower than the average. If it was established with certainty that the vegetation found in undisturbed sites of Forest-Tundra and Open Coniferous Forest areas is essential for these animals as winter range, then the apparent impoverishment of vegetation by fire, together with slow recovery, might well be an important factor in their ecology. To what extent it is responsible for the well-established diminution of herds is not clear, but it is a field of inquiry that deserves close attention (cf. Darling and Leopold).

On the photographs the Open Coniferous Forest presents a characteristic appearance. The spire-shaped spruces can be seen easily under a magnifying stereoscope; they form a coarse stippling of dark grey (N4) on a ground vegetation background of smooth, light grey (N7 or 6) appearance. Patches of bog and muskeg are readily recognized by the criteria given under ForestTundra.

Throughout the zone there is considerable relief with ridges and undulating hills of drift, large eskers, and local drumlin fields.

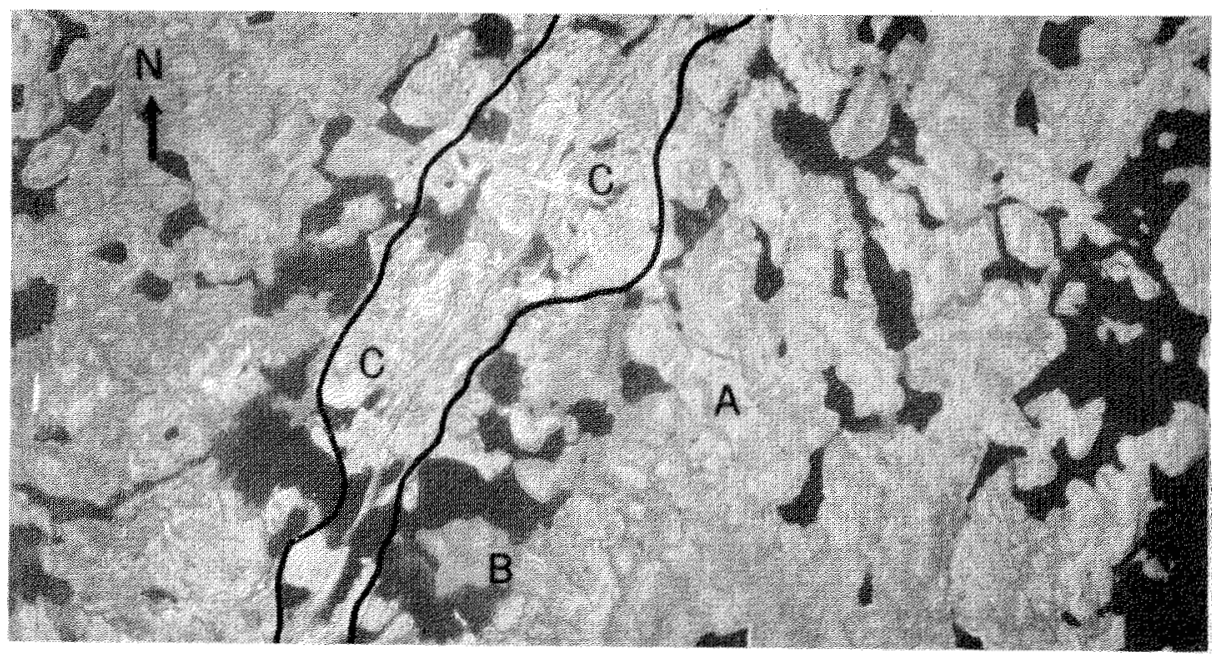

Fig. 5. Vertical air photograph A 15707-74 (scale 1:60,000) showing an area of Open Coniferous Forest in the northwest corner of the province. Areas outlined are glacial drift with open spruce-lichen forest (A), peat-filled depressions with moss muskeg (B), and an esker ridge and apron with open spruce-lichen forest (C).

\section{(d) Closed Coniferous Forest (Fig. 6)}

This zone can be divided into approximately equal western and eastern areas which are, however, not shown on the map (Fig. 2). They are separated on the basis of a difference in the proportion of poorly drained, predominantly peat-covered land to forested upland areas. In the western section the area occupied by bogs and muskegs is not greater than 50 per cent of the total 
area, whereas in the eastern part it comprises 50 to 80 per cent. The western area shows a prevalence of closed-crown forests on mesic sites, and the few areas that show no recent disturbance by fire bear a closed stand of Picea mariana with a thick carpet of weft- and tuft-form mosses as the only subsidiary layer. After fire various seral types are found, and Pinus banksiana (jackpine) and Betula papyrifera (white birch) are the chief tree species to follow pioneer shrub stages. These subseral details have been described elsewhere (Ritchie 1956). Rock ridges, eskers, and sandplains bear stands of jackpine, and peats are covered by muskeg and treeless bog. A part of this zone that is judged to be representative of the whole has been mapped in detail (Ritchie 1958).

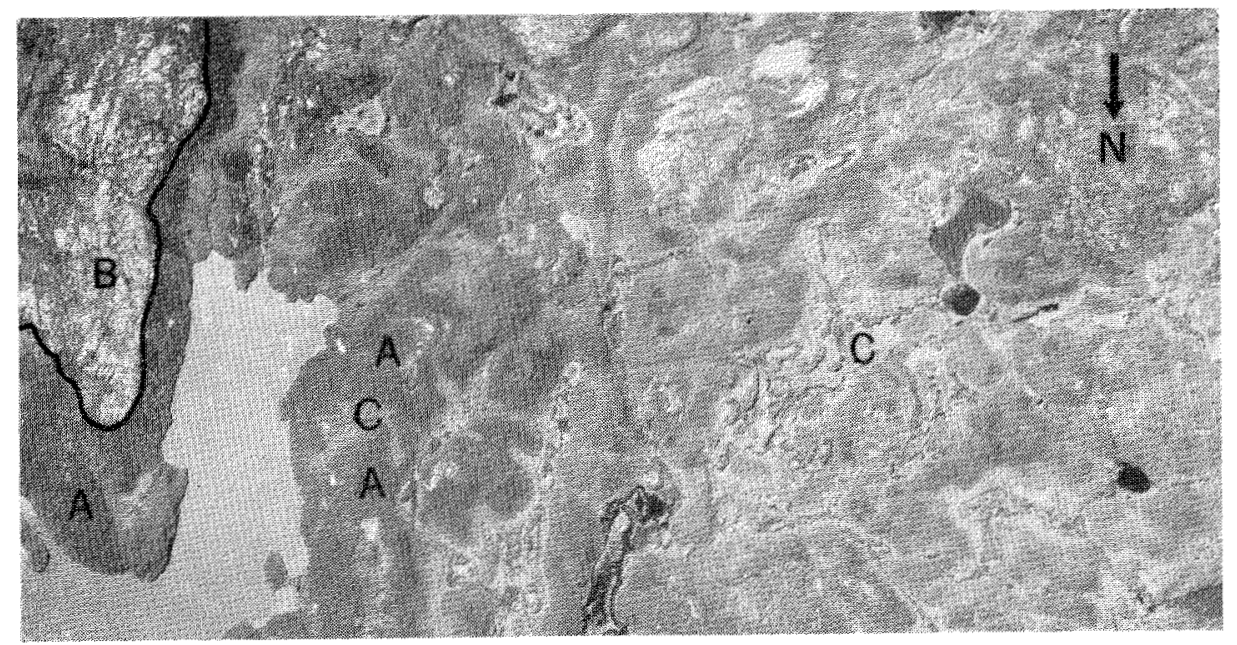

Fig. 6. Vertical air photograph A 14889-133 (scale 1:60,000) showing an area of Closed Coniferous Forest at McBride Lake. Upland types shown are closed forest (A), here dominated by spruce with occasional birch; and an open jackpine community on outcropping bedrock (B). Depressions are occupied by bog complexes (C).

The western section of the zone shows marked physiographic differences from the eastern. In the west relief is considerable, with ridges of bedrock becoming more numerous towards the Saskatchewan boundary and drift ridges, sandplains, and eskers common everywhere. The eastern part is gently rolling and has extensive shallow basins occupied by lakes and large tracts of peat covering the drift. Shallow lacustrine deposits are common here and were apparently formed by the northern extension of Glacial Lake Agassiz (Glacial Map of Canada, 1958).

A detailed account of the photographic characteristics of this zone has been published (Ritchie 1958). It is sufficient here to point out that the diagnostic cover type, the closed-crown coniferous forest on upland sites, is readily recognized by its dark grey tone (N4) and even stippling. 


\section{Hudson Bay Lowlands}

Two general facts about the tentative categories of the vegetation zones of the Hudson Bay Lowlands have emerged from an examination of the area on the ground, from the air, and by inspection of air photographs: (a) that one can recognize on floristic and structural grounds certain categories of vegetation that occupy large, often discontinuous tracts of the lowlands; (b) that these types recur with floristic and structural consistency. They are tabulated and listed below with a brief explanation of their main features. Clearly, these eleven categories are not all of comparable rank, whether one considers them from seral or static points of view, and they are put forward here merely as a first step. Subsequent work will certainly expand and refine the list, not only by recognizing smaller groups within the present ones, but by presenting quantitative data to illustrate the degree of constancy of the various groups. (A forthcoming paper on the vegetation of the lower Hayes River area will make available detailed descriptions of many of these types). Further work will also permit clarification of the status of the groups in terms of both seral and static features, so that they can be arranged in a valid hierarchy. Much work is required before this will be possible, but investigation is proceeding along lines that will make possible classification in terms of dynamic and static attributes.

The following table sets out this preliminary, highly tentative separation.

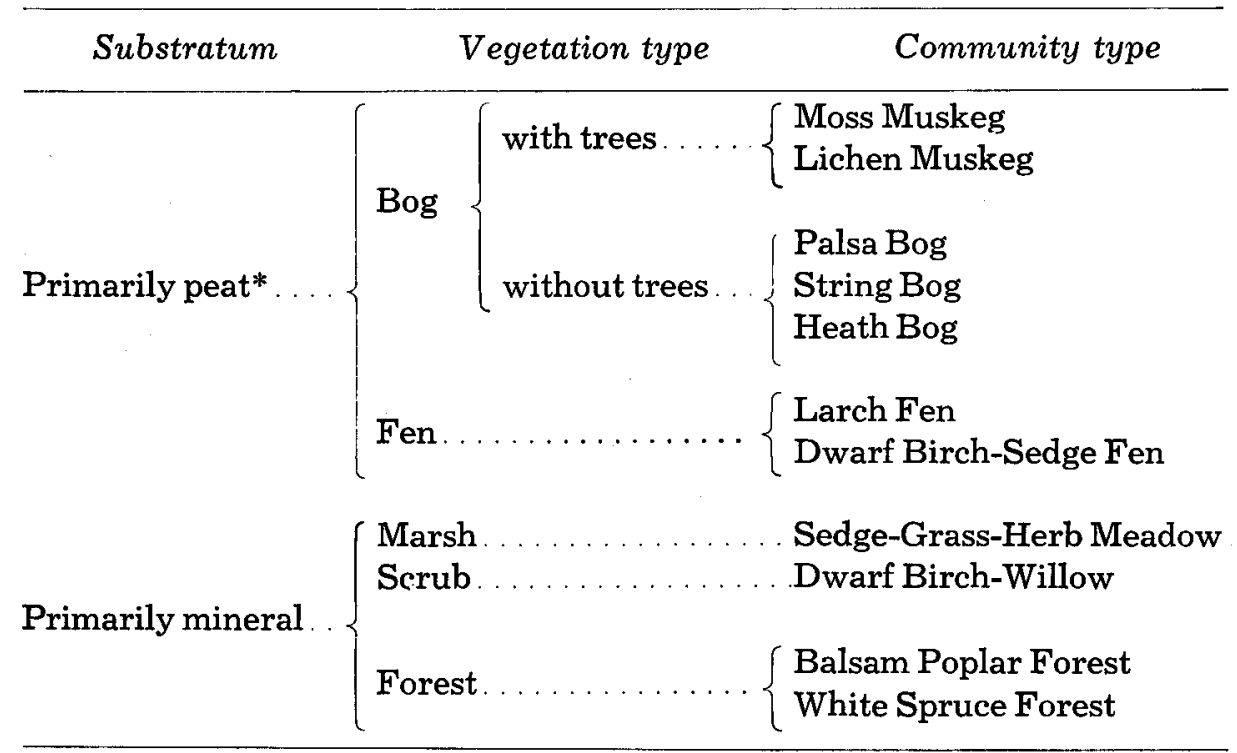

*This division of the vegetation on peat is tentative, but an attempt has been made to align it with the classical approach of Cajander (1913), which has been adopted widely in Europe (e.g. Sjörs 1948, Tansley 1952).

The following provides brief general descriptions of the above community types. 
Moss Muskeg. - This is the type that has been referred to in earlier publications simply as "muskeg" (Hustich 1949; Ritchie 1956, 1959). The characteristics are: an open stand of depauperate Picea mariana on acid peat; the ground vegetation dominated by mosses, often forming hummocks (chiefly Sphagnum fuscum, S. warnstorfianum, Aulacomnium palustre); a low shrub stratum of Ledum groenlandicum with other ericoid shrubs, and a sparse medium shrub stratum of Salix species and Betula glandulosa.

Lichen Muskeg. - This type bears close physiognomic resemblances to Moss Muskeg, differing in the replacement of the moss carpet by a lichen cover, dominated by Cladonia rangiferina and C. alpestris. The Ledum element is present and covers only slightly less of the ground than the lichens, being associated with small amounts of other low shrubs (Vaccinium uliginosum, $V$. vitis-idaea ssp. minor, and Empetrum hermaphroditum). Vegetation of this type is common in the lowlands along drainage channels on levees, and as raised islands in vast areas of Larch Fen and Bog.

Palsa Bog. - Palsas are small mounds of peat with cores of permafrost, capped by a Ledum-Sphagnum-Carex community, with scattered black spruce trees locally. This type forms large complexes, with wet sedge peat or open water between individual palsas.

String Bog. - This consists of parallel ridges of peat that are raised 0.5 to $2.0 \mathrm{~m}$. above the level of the surrounding water or bog, and that usually run parallel to the contours. The ridges bear a shrub, or locally a larch community, with the surface cover made up of Sphagnum hummocks, Carex sp., and small ericaceous shrubs (Andromeda, Ledum, Vaccinium vitis-idaea ssp. minor). The intervening areas are often covered with open, shallow water or Carex and Drepanocladus-Calliergon communities.

Heath Bog. - This term is given to extensive tracts of more or less treeless vegetation on deep $(1 \mathrm{~m}$.) peats, found especially in the northern part of the area. The vegetation is dominated by Ledum groenlandicum, $L$. decumbens, and Empetrum hermaphroditum associated with Cladonia alpestris, C. mitis and species of Sphagnum.

Larch Fen. - This develops on wet, shallow peats, where there is some influence near the surface from the mineral substratum. The peat is neutral or slightly basic. Depauperate, widely spaced trees of Larix laricina dominate and there is a dense shrub layer of Betula glandulosa, Salix pedicellaris var. hypoglauca. The ground vegetation is a moss-sedge-prostrate shrub complex, with Tomenthypnum nitens, Drepanocladus spp., Campylium stellatum, Carex chordorrhiza, C. tenuiflora, C. diandra, Eriophorum viridi-carinatum as the main species and a rich herb component.

Dwarf Birch-Sedge-Fen. - This is very similar in composition to the Larch Fen, and the main difference is the absence of larch.

Sedge-Grass-Herb-Meadow. - This is a marsh type, often salt marsh and found on tidal flats at the coast and estuaries. It has been previously described (Scoggan 1951) as tundra or barren extending down the western shore of Hudson Bay. It is primarily the plant cover of recent alluvial or marine deposits, marshy in character, and dominated by Carex (C. stans, C. 
paleacea, C. aquatilis), grasses (Dupontia fisheri, Puccinellia distans, Colpodium fulvum), Triglochin maritima, and a rich herb component (Primula egaliksensis, Parnassia multiseta, Lomatogonium rotatum etc.). It is a seral type, being invaded by Dwarf Birch-Willow, Balsam Poplar Forest, and White Spruce Forest.

Dwarf Birch-Willow. - Large tracts of land adjacent to marsh flats, and on river islands and shorelines are occupied by dense shrubby vegetation. The chief species are willows (Salix brachycarpa, S. cordifolia, and S. rigida) and dwarf birch (Betula glandulosa).

Poplar Forest. - On some older alluvial and beach deposits dense stands of Populus balsamifera with a sparse ground cover of herbs are common. In many places young trees of Picea glauca are invading these stands.

White Spruce Forest. - On other old alluvial deposits excellent stands of white spruce are found. They are pure, with sparse subsidiary shrub strata. The ground vegetation is either a predominantly herbaceous community (chief species Cornus canadensis, Linnaea borealis ssp. americana, Mitella nuda, Geocaulon lividum, Pyrola secunda) or a predominantly moss-dwarf shrub community (Hylocomium splendens, Pleurozium schreberi, Salix myrtillifolia, Vaccinium vitis-idaea ssp. minor, Arctostaphylos rubra).

The main vegetation zones of the Hudson Bay Lowlands are the following (see Fig. 1).

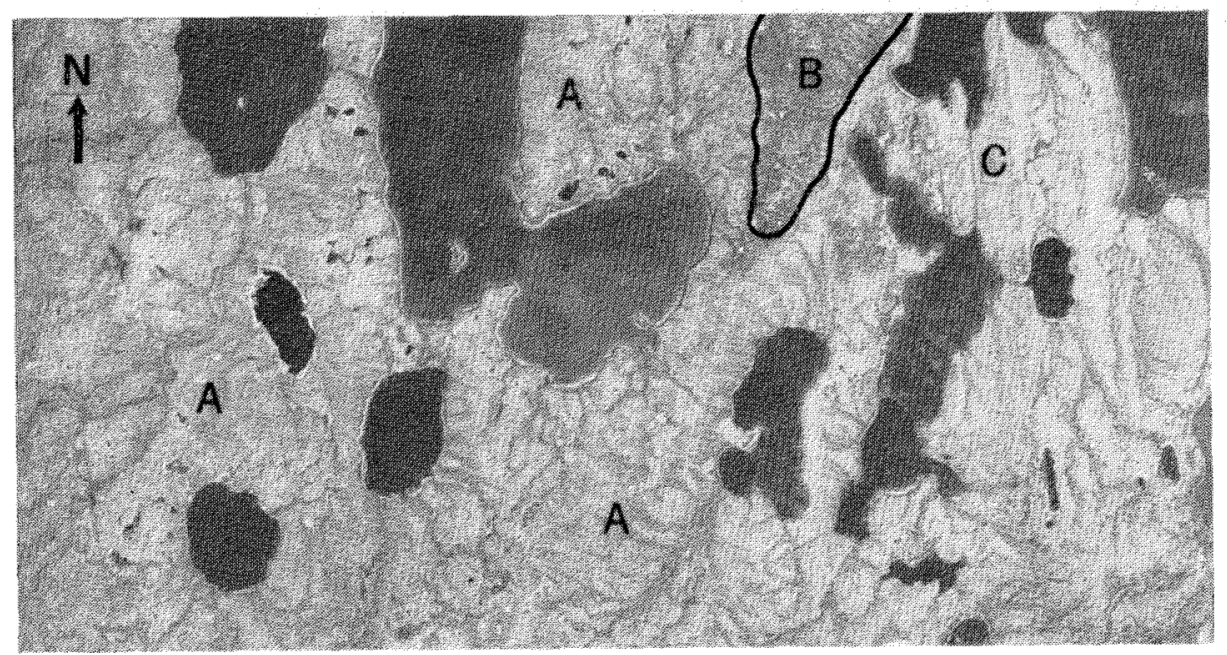

Fig. 7. Vertical air photograph A 14977-123 (scale 1:60,000) showing an area of Transitional Type between the Hudson Bay Lowlands proper and the Canadian Shield. Most of the area has only slight relief with extensive moss muskeg (A). Upland sites bear open coniferous forest (B) and (C), the latter growing on a raised beach.

\section{(a) Transition Type (Fig. 7)}

This forms the boundary zone between the Canadian Shield and the Hudson Bay Lowlands in Manitoba and is transitional, both in vegetation 
and physiography. The vegetation in the southern two-thirds of the area is predominantly a Moss Muskeg community on deep peat, whereas in the north there are extensive peats without trees and with conspicuous polygon features (the latter are the Heath Bogs). The muskeg vegetation has been described above. Occasional upland features, such as drift hills, beaches, or drumlins are occupied by either open spruce-lichen forests or closed spruce-feather moss forests. In the wetter sites there are Treeless Bogs, often of the StringBog Type.

Relief is poor and shows only slight undulations. Dendritic drainage patterns prevail locally, and many areas have large numbers of small lakes.

On the photographs, the predominant muskeg type is grey to dark grey (N5 to N4) and has faint stippling, with the individual trees just visible under the magnifying stereoscope. A marked increase in the height of black spruce is seen along drainage channels. On upland sites, Open Coniferous and Closed Coniferous Forests can be distinguished by the criteria given above.

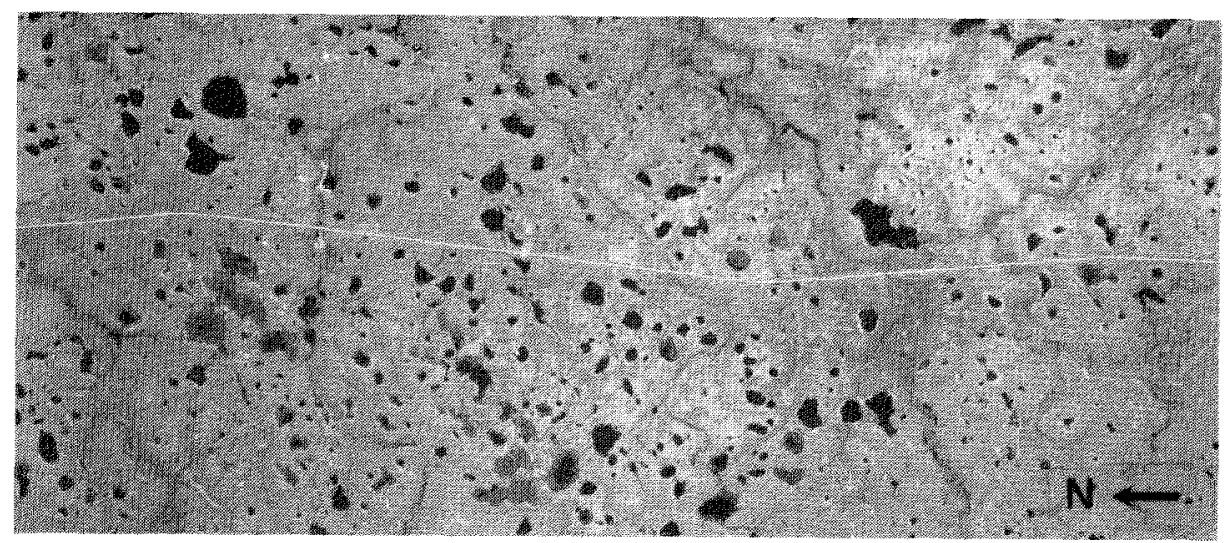

Fig. 8. Vertical air photograph A 14126-15 (scale 1:60,000) showing an area along the Hudson Bay Railway at about $57^{\circ} 50^{\prime} \mathrm{N}$. occupied by Moss Muskeg. The land is almost entirely covered with a mantle of peat bearing moss muskeg and shows slight ponding and dendritic drainage patterns, which are characteristic of the entire zone.

\section{(b) Moss-Muskeg Type (Fig. 8)}

This zone occurs only in the Hudson Bay Lowlands proper and the characteristic vegetation is the Moss-Muskeg community on deep $(60-200 \mathrm{~cm}$.) peat. Along the watercourses there are dense stands of shrubs (Salix planifolia, Betula glandulosa, Alnus rugosa ssp. americana) and occasional small stands of conifers (Picea glauca and Larix laricina) on alluvial substrata.

The terrain is flat, with extensive dendritic drainage patterns and moderate local ponding. The only relief is provided by a few raised beaches and gravel bars. In places large areas of peat are arranged in slight, irregular mounds.

On the photographs, the gross features are the dendritic drainage patterns, moderate ponding and irregular, crenate peat deposits, usually about 
$100-500 \mathrm{~m}$. in diameter. The main vegetation type (Moss-Muskeg) is grey (N5) and light grey (N6) where the spruces are sparse.

\section{(c) Treeless Bog Type (Fig. 9)}

This zone occupies a northern and central position in the Hudson Bay Lowlands, and is characterized by the prevalence of treeless vegetation on peat. It is a region of excessively poor drainage, with abundant ponds, many small lakes, and wet bogs. There are two main types of plant cover: a) fragmentary Moss-Muskeg with depauperate trees of Picea mariana; b) Treeless Bog, the most common type in this zone, dominated by heath vegetation and sedge-cotton grass vegetation, the latter in wetter sites. Large polygon patterns are common in this zone. Only along streams and rivers is there any fair tree growth, and here stands of Picea glauca and Larix laricina are found on mineral soil.

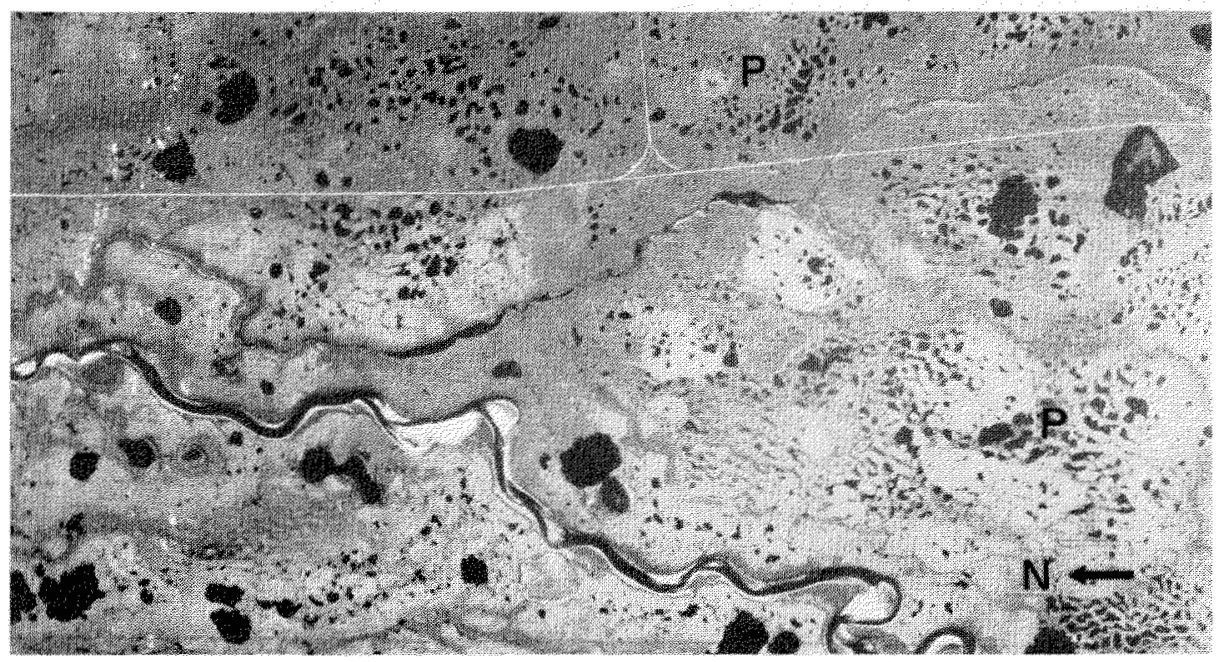

Fig. 9. Vertical air photograph A 14126-2 (scale 1:60,000) showing the characteristic excessively ponded, poorly drained nature of the land in the Treeless Bog zone near $58^{\circ} 10^{\prime} \mathrm{N}$. on the Hudson Bay Railway. Tree growth is confined to the main water courses. Palsa bog occurs occasionally $(P)$, and the extensive polygon patterns on the bog surface are just visible in the areas between the two main streams.

Only gravel and sand deposits provide any relief in this zone and drainage patterns are immature or lacking. The surface is characterized by innumerable shallow ponds and lakes, with local development of Palsa Bog. Permafrost is present in many of the drier peat deposits, with the active layer $30-50 \mathrm{~cm}$. in depth.

On the photographs, the excessive ponding, occasional Palsa Bogs and the fine reticulate pattern of the peat polygons are characteristic. The heath tundra is grey to light grey (N6 to N7), the treeless sedge-cotton grass bogs are light grey to white (N7 to N8), and the shrub and tree vegetation along 
watercourses is grey (N5). In this last type individual trees can often be made out under the stereoscope.

\section{(d) Lowland Complex (Fig. 10)}

Within the area of the Hudson Bay Lowlands mapped in Fig. 1 as "Lowland Complex", there are several distinct and important vegetation types. However, none of them occupies continuous areas large enough to make possible more detailed mapping at this scale. (These subdivisions will be mapped separately in the 1:500,000 maps of this region). The types of vegetation included in this complex are as follows, using the terms described above:

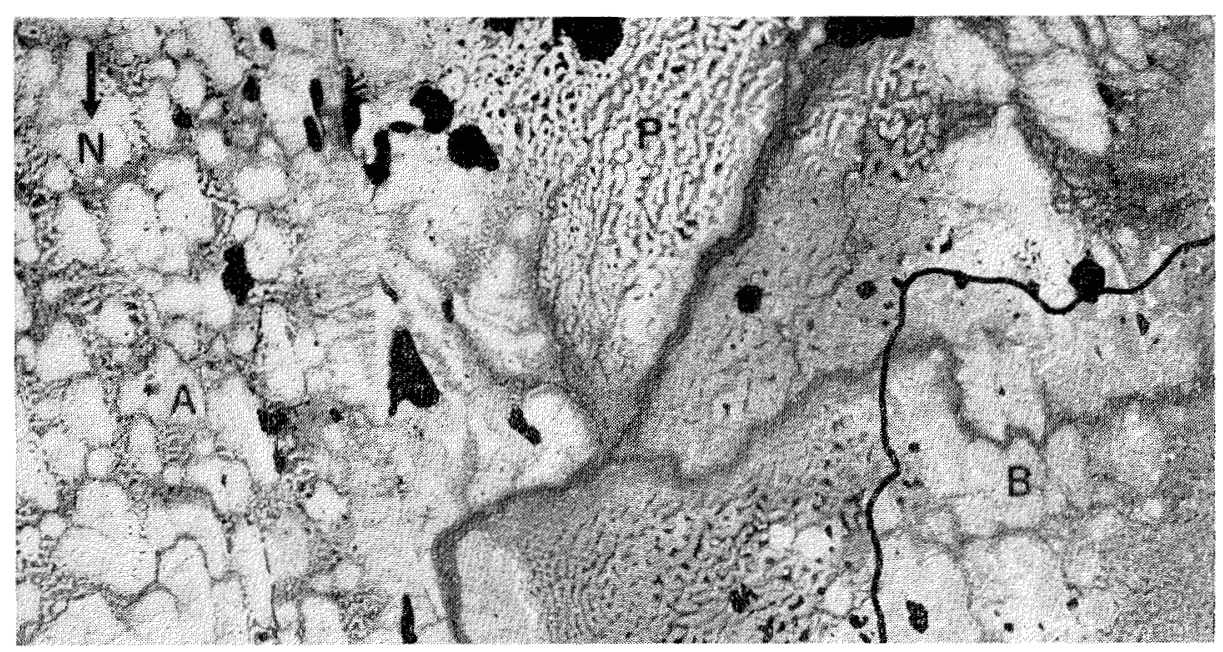

Fig. 10. Vertical air photograph A 14219-86 (scale 1:60,000) in the Hudson Bay Lowland Complex zone near York Factory on the Lower Hayes River. Three types are shown here: extensive tracts of lichen muskeg on weathered beaches (A), areas of shrub that have replaced lichen muskeg after fire (B), and palsa bogs in poorly drained regions (P).

Moss Muskeg, Lichen Muskeg, Palsa Bog, String Bog, Larch and Scrub Fen, Sedge-Grass-Herb-Meadow, Treeless Bog, Balsam Poplar Forest, and White Spruce Forest. In general, older parts of this zone, usually farther inland, are covered with a mantle of poorly drained peat whose depth seldom exceeds $1 \mathrm{~m}$. Often on levees along watercourses and as isolated raised islands in continuous areas of wet bog or fen is to be found one of the most striking types of vegetation. This is the Lichen Muskeg type that covers large areas in Fig. 10. Wetter parts of these older deposits bear Treeless Bog or Fen and the exact nature of the vegetation apparently depends on the depth of the peat, the movement of water in the peat or both. Where there is lateral movement of water carrying mineral nutrients neutral or basic peat is formed with a distinctive fen vegetation. Where there is no influx of mineral material, either directly or in minerotrophic water the peat is acid and bears a bog vegetation. On river banks, islands, and young beaches are zones of shrub 
and tree vegetation, the former dominated by Salix planifolia, S. rigida, and Betula glandulosa, the latter by Picea glauca and Populus balsamifera. Fig. 11, showing part of the delta of the Knife Rivers, where estuary deposits of calcareous alluvium are found, illustrates this type. On the older alluvial sites excellent stands of white spruce are found.

Extensive flats are being exposed along the coastline as the land rises. They are occupied by marsh vegetation and later invaded by shrubs. In older, usually slightly better drained sites a tree zone occurs that is dominated by Picea glauca, with Populus balsamifera in the southern parts of the Hudson Bay Lowlands.

The entire zone is poorly drained and the interfluves are occupied by bogs. The few rivers have steep banks that are cut into the marine clays, and many of the tributaries meander extensively. Slight relief is provided by beaches, bars, and spits, and at Churchill there is a unique outcrop of bedrock.

On the photographs gross patterns, the result of both the appearance of the vegetation and of physiographic processes, are easily recognized. The following table summarizes the main characteristics of the vegetation, as seen under a magnifying stereoscope.

\begin{tabular}{|c|c|c|}
\hline Vegetation type & Tone & Texture and appearance \\
\hline Lichen Muskeg & $\begin{array}{l}\text { light grey to } \\
\text { white (N7 - N8) }\end{array}$ & $\begin{array}{l}\text { Large, crenate mounds or continuous } \\
\text { tracts along watercourses and beaches, } \\
\text { the trees are denser at the margins; the } \\
\text { individual trees are depauperate, but can } \\
\text { be seen clearly under X } 4 \text { magnification. }\end{array}$ \\
\hline Treeless Bog & $\begin{array}{l}\text { grey to white } \\
\text { (N6-N8) }\end{array}$ & $\begin{array}{l}\text { Flat and treeless; Palsa and String Bogs } \\
\text { have characteristic patterns (Fig. 9). }\end{array}$ \\
\hline Fen & $\begin{array}{l}\text { dark grey to } \\
\text { grey (N5 - N6) }\end{array}$ & $\begin{array}{l}\text { Flat, lacking pattern, but often with many } \\
\text { small elongate ponds (flarks); the diffuse } \\
\text { effect of fens with trees (larch) is visible }\end{array}$ \\
\hline $\begin{array}{l}\text { White Spruce } \\
\text { Forest }\end{array}$ & grey (N6) & $\begin{array}{l}\text { Individual spire-shaped trees clearly visi- } \\
\text { ble, the closed-crown stands making a } \\
\text { coarse stippling. }\end{array}$ \\
\hline $\begin{array}{l}\text { Balsam Poplar } \\
\text { Forest }\end{array}$ & $\begin{array}{l}\text { grey to dark } \\
\text { grey (N6 - N7) }\end{array}$ & $\begin{array}{l}\text { Diffuse, fluffy appearance of crowns, in- } \\
\text { dividual trees not visible; slightly irregu- } \\
\text { lar surface texture. }\end{array}$ \\
\hline Marsh & $\begin{array}{l}\text { light grey } \\
\text { (N7) }\end{array}$ & Flat, textureless, and structureless. \\
\hline Shrub & $\begin{array}{l}\text { grey to light } \\
\text { grey (N6) }\end{array}$ & Flat, textureless, and structureless. \\
\hline
\end{tabular}




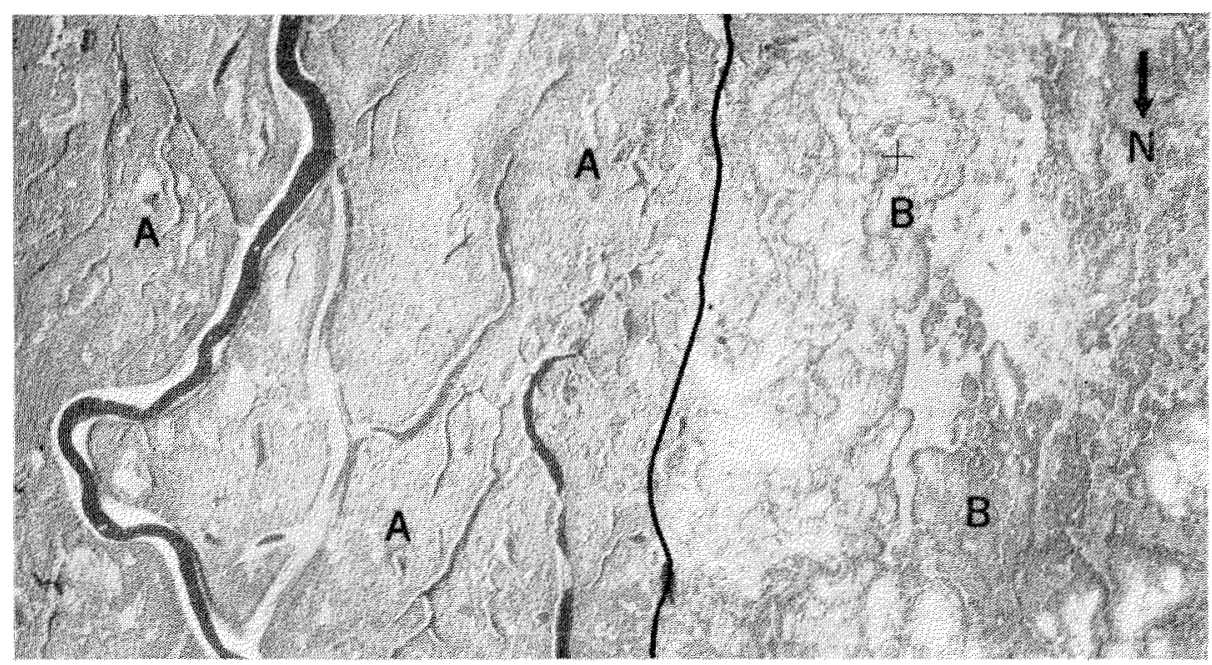

Fig. 11. Vertical air photograph A 11022-244 (scale 1:60,000) near the mouth of Knife River. Two main categories of vegetation are shown: extensive stands of Closed White Spruce Forest on recent alluvium (A), and an area of island-like mounds of peat (B), surrounded by continuous fen and bog vegetation. The peat "islands" show a peripheral zone of moss muskeg and a central zone of lichen muskeg (or tundra in some areas).

\section{Concluding Comment}

Although the exact position of the boundaries will be changed as more detailed mapping at a larger scale proceeds, the general configuration of the zones will probably retain validity. Furthermore, whereas later field work will make possible a more detailed subdivision of the categories, particularly on the Hudson Bay Lowlands, it is likely that the account given here provides a balanced view of the chorology of the vegetation in the region. The lines along which this work will be pursued in future are (a) extension of the detailed descriptive studies of particular areas, (b) exploration of the possibilities of correlating the major zones of vegetation with boundaries between environmental regions, and (c) continuation of a detailed survey of the literature on the vegetation of the subartic zone in all parts of the Northern Hemisphere.

These investigation have been supported generously by the National Research Council of Canada, the Arctic Institute of North America, and the University of Manitoba. 


\section{References}

Banfield, A. W. F. 1954. Preliminary investigations of the Barren Ground caribou. I and II. Wildlife. Bull., Ser. 1, $10 \mathrm{~A}$, pp. 1-79, $10 \mathrm{~B}$, pp. 1-112.

Beckel, D. K. B. 1958. A pilot study of caribou winter range, Brochet, Manitoba, by means of airphoto analysis and interpretation. Can. Wildlife Serv., (unpublished).

Cajander, A. K. 1913. Studien über die Moore Finnlands. Acta for. fenn. 2, No. 3, $208 \mathrm{pp}$.

Cheney, T. A., and D. K. Brown Beckel. 1955. Fort Churchill environmental analysis. Cornell Univ., Ithaca N.Y., 349 pp. (unpublished).

Coombs, D. B. 1954. The physiographic subdivisions of the Hudson Bay Lowlands south of 60 degrees north. Geog. Bull. 6:571-85.

Glacial Map of Canada, 1958. Published by Geol. Assoc. of Can.

Hare, F. K. 1955. Mapping of physiography and vegetation in Labrador-Ungava, a review of reconnaissance methods. Can. Geog. 5:17-28. 1959. A photo-reconnaissance survey of Labrador-Ungava. Dept. of Mines and Technical Surveys, Geographical Branch, Ottawa. Mem. 6, 83 pp.

Hare, F. K., and R. G. Taylor. 1956. The position of certain forest boundaries in southem Labrador-Ungava. Geog. Bull. 8:51-73.

Hustich, I. 1949. On the forest geography of the Labrador Peninsula Acta Geog. 10, No. 2,63 pp.

1957. On the phytogeography of the Hudson Bay Lowland. Acta Geog. 16, No. 1,48 pp.

Radforth, N. W. 1952. A suggested classification of muskeg for the engineer. Nat. Res. Coun. Can. Tech. Mem. No. 24.

1958. Organic terrain organization from the air. Handbook No. 2, Def. Res. Bd., Rep. No. D.R. 124, 23 pp.

Ritchie, J. C. 1956-59. The vegetation of northern Manitoba. I. Can. J. Bot. 34:523-61; II. Ecology 38:429-35; III. Tech. Pap. No. 3, Arct. Inst. of N. Am., 56 pp.; IV. The Caribou River area. Can. J. Bot. 38:185-99.

1958. A vegetation map from the southern Spruce Zone of Manitoba. Geog. Bull. 12:39-46.

Scoggan, H. J. 1957. Flora of Manitoba. Nat. Mus. Can., Bull. 140, 610 pp.

Sjörs, H. 1948. Myrvegetation i Bergslagen. Acta phytogeog. suecica 21, 299 pp.

1958. Bogs and fens in the Hudson Bay Lowlands. Arctic 12:3-19.

Tansley, A. G. 1950. The British Isles and their Vegetation. London. Cambridge University Press, $930 \mathrm{pp}$. 